Original Research Article

\title{
An assessment of available treatment facilities at different treatment centers of Sikkim: a cross sectional baseline study from dependents' perspective
}

\author{
Sunil K. Pandey*, Deepanjana Dass
}

Department of Pharmacology, Sikkim Manipal Institute of Medical Sciences, Gangtok, Sikkim, India

Received: 12 July 2017 Accepted: 19 July 2017

\section{*Correspondence to: Dr. Sunil K. Pandey, Email: sunilmanipal@ gmail.com}

Copyright: () the author(s), publisher and licensee Medip Academy. This is an openaccess article distributed under the terms of the Creative Commons Attribution NonCommercial License, which permits unrestricted noncommercial use, distribution, and reproduction in any medium, provided the original work is properly cited.

\begin{abstract}
Background: Substance dependence is a major challenge for the economic wellbeing of an individual, society or a country. There is a huge gap between treatment demand and supply. Treatment facilities provided by the centers are different and are many a times lesser and inferior than required. This study was aimed to explore the status of basic facilities in the treatment centers of Sikkim from dependents' perspectives.

Methods: This study was conducted with $n=241$ participants who were undergoing treatment in seven different treatment centers of Sikkim. Reliable and pre-validated sociodemographic and treatment facility questionnaires were administered by the investigator on personal interview. Answers were recorded on the questionnaire and the same was entered in SPSS following which frequency and chi square analysis was done.

Results: There were more male participants than females. Also, more number of participants were from Nepali, Hindu and urban origin. $31 \%$ participants were found to be unemployed. Knowledge about other treatment centers was fair $(66 \%)$ and maximum had the knowledge of present treatment facilities. More than $90 \%$ participants were not satisfied with the contact facilities and nutritional supplements (98\%). At around $41 \%$ participants reported that the education sessions were either boring or useless or both.

Conclusions: In order to increase the entry in the treatment, there is a need to improve the quality of different facilities at the treatment centers. Also, there is a need of intermittent audit of the minimum required facilities.
\end{abstract}

Keywords: Alcohol, Dependence, Substance, Treatment

\section{INTRODUCTION}

Substance dependence negatively affects an individual along with the society and also indirectly affects the economic health of the country. Risk factors like rapid lifestyle change, home environment and workplace atmosphere are clearly responsible for increasing the number of dependence. ${ }^{1,2}$ Reasons like fear of withdrawal, doubt about benefit of treatment, and treatment facilities are some of the factors responsible for not availing treatment facilities by substance dependents. Data of National Family Health Survey-3 (NFHS-3) shows a prevalence rate of $45.4 \%$ and $19.1 \%$ among $15-49$ years of age in males and females of Sikkim, respectively. ${ }^{3}$ Drug abuse is also a rising challenge in Sikkim, where students were reported to be indulged in inhaling dendrite (a volatile contact adhesive (glue) used for sticking wooden material, rubber, leather etc. and misused as an inhalant) and consuming alcohol and tobacco. ${ }^{4}$ Since there is lack of information on standard type and facilities available for the treatment seekers in treatment centres, the objective of this study was to describe the treatment facilities for the substance dependents who were undergoing treatment in rehabilitation centres in Sikkim. 


\section{METHODS}

This study was conducted in seven treatment centers, which includes five rehabilitation centers and one each of private tertiary care hospital and public hospital. Data was collected over a period of one year and nine months (March 2011 to December 2012). The target participants were any type of substance dependents who were availing treatment facilities in any of these seven centers. Repeated and intermittent visit was made to meet the calculated number of participants $(n=220)$. By the end of the study a total of $n=241$ participants were enrolled.

Two reliable and pre-validated questionnaires were administered among participants. The first was sociodemographic based questionnaire whereas the second carried questions on facilities present in the treatment centers. One-to-one interviews was conducted between the participant and the investigator after taking due permission from the concerned authorities. Signature of the participants was taken on the written informed consent after due information regarding the study. Participants were also given a copy of informed consent. Responses were recorded directly on the questionnaire which later on was fed in the analytical software (SPSS, version 20.0, IBM). Data was first cleaned and then analyzed using frequency and chi square test. Level of significance was set at $\mathrm{p}<0.05$.

\section{RESULTS}

Table 1 shows sociodemographic characteristics of participants. There were more male participants compared to females. Only two rehabilitation centers had female enrolments. Education wise most of the participants had not completed their studies (37\%) and also were unemployed (31\%). Since there is more Nepali and Hindu population in Sikkim, the same is reflected in the results too.

Table 2 proposes respondents' impression about the treatment centers and facilities available. $66 \%$ participants had knowledge about availability of treatment centers. Most of the subjects had the knowledge of availability of treatment facilities or services like detoxification, types of treatment, availability of inpatient or outpatient services and rehabilitation facility. Around 31\% subjects reported that there was scarcity of available beds. Subjects were satisfied with the type of food served but at the same time 98\% mentioned that they were devoid of nutritional supplements. Transport facility to and from the centers was well available. Majority of the participants reported that rules and regulations were moderately strict to very strict. Education sessions were found to be interesting and useful by $56.8 \%$ participants. There was no significant difference in knowledge about availability of treatment center by source of income $\left(\chi^{2}=0.34, \mathrm{df}=3, \mathrm{p}=0.95\right)$ or by rural / urban residence $\left(\chi^{2}=0.11, \mathrm{df}=1, \mathrm{p}=0.74\right)$. Information about available treatment facility and services had no association with the main substance problem, i.e., only alcohol, other substances or both $\left(\chi^{2}=4.61, \mathrm{df}=4, \mathrm{p}=\right.$ $0.33)$ or by rural / urban residence $\left(\chi^{2}=1.49, \mathrm{df}=2, \mathrm{p}=0.48\right)$. However, education had a significant association with knowledge about availability of treatment center with school drop outs having poorer knowledge $\left(\chi^{2}=13.30\right.$, $\mathrm{df}=4, \mathrm{p}=0.01)$. Similarly, education also had a significant association with available treatment facility and services with school dropouts having little or no information $\left(\chi^{2}=16.10, \mathrm{df}=8, \mathrm{p}=0.03\right)$.

Table 1: Basic sociodemographic profile of participants $(n=241)$.

\begin{tabular}{|c|c|c|c|}
\hline Variables & Category & $\begin{array}{l}\text { Frequency } \\
\text { (n) }\end{array}$ & $\begin{array}{l}\text { Percentage } \\
(\%)\end{array}$ \\
\hline \multirow{2}{*}{ Gender } & Male & 226 & 93.8 \\
\hline & Female & 15 & 6.2 \\
\hline \multirow{4}{*}{ Education } & Illiterate & 26 & 10.8 \\
\hline & $\begin{array}{l}\text { School drop } \\
\text { out }\end{array}$ & 89 & 37.0 \\
\hline & $\begin{array}{l}\text { School } \\
\text { completed }\end{array}$ & 87 & 36.1 \\
\hline & Graduation & 39 & 16.1 \\
\hline \multirow{5}{*}{ Occupation } & $\begin{array}{l}\text { Self } \\
\text { employed } \\
\text { (Other than } \\
\text { business) }\end{array}$ & 67 & 27.8 \\
\hline & Officials & 44 & 18.3 \\
\hline & Business & 41 & 17.0 \\
\hline & Students & 14 & 5.8 \\
\hline & Unemployed & 75 & 31.1 \\
\hline \multirow{2}{*}{ Community } & Urban & 165 & 68.5 \\
\hline & Rural & 76 & 31.5 \\
\hline \multirow{4}{*}{ Ethnicity } & Lepcha & 5 & 2.1 \\
\hline & Bhutia & 34 & 14.1 \\
\hline & Nepali & 161 & 66.8 \\
\hline & Others & 41 & 17.0 \\
\hline \multirow{5}{*}{ Religion } & Hindu & 117 & 48.5 \\
\hline & Buddhism & 74 & 30.7 \\
\hline & Islam & 1 & 0.4 \\
\hline & Christianity & 41 & 17.0 \\
\hline & Others & 8 & 3.3 \\
\hline \multirow{4}{*}{$\begin{array}{l}\text { Socioecono } \\
\text { my, income } \\
\text { (INR) }\end{array}$} & $0-10000$ & 178 & 73.9 \\
\hline & $10001-20000$ & 40 & 16.5 \\
\hline & $20001-30000$ & 18 & 7.5 \\
\hline & $>30000$ & 05 & 2.1 \\
\hline
\end{tabular}

\section{DISCUSSION}

The present study had fewer numbers of female participants $(6.2 \%)$ than males which supports the statement "substance abuse in women still attracts greater social stigma than in men, with attendant efforts by women to hide the problem and by the caregivers in not recognizing the problem, thereby limiting treatmentseeking." 
Table 2: Non pharmacological treatment facilities and its knowledge to participants $(\mathbf{n}=\mathbf{2 4 1})$.

\begin{tabular}{|c|c|c|c|}
\hline Variable & Category & Frequency & Percentage \\
\hline \multirow{2}{*}{$\begin{array}{l}\text { Knowledge about other } \\
\text { treatment centers }\end{array}$} & Yes & 159 & 66.0 \\
\hline & No & 82 & 34.0 \\
\hline \multirow{25}{*}{$\begin{array}{l}\text { Treatment facility/services } \\
\text { available }\end{array}$} & a) Intake, assessment or referral & & \\
\hline & Yes & 60 & 24.9 \\
\hline & No & 71 & 29.5 \\
\hline & Don’t know & 110 & 45.6 \\
\hline & b) Detoxification & & \\
\hline & Yes & 219 & 90.9 \\
\hline & Don’t know & 22 & 9.1 \\
\hline & c) Treatment of substance abuse & & \\
\hline & Yes & 235 & 97.5 \\
\hline & No & 2 & 0.8 \\
\hline & Don’t know & 4 & 1.7 \\
\hline & d) Counselling & & \\
\hline & Yes & 238 & 98.8 \\
\hline & No & 3 & 1.2 \\
\hline & e) General healthcare and substance abuse tr & nent services & \\
\hline & Yes & 235 & 97.5 \\
\hline & Don’t know & 06 & 2.5 \\
\hline & f) Mental health services & & \\
\hline & Yes & 159 & 66.0 \\
\hline & No & 52 & 21.6 \\
\hline & Don’t know & 30 & 12.4 \\
\hline & g) Mix of mental health and substance abuse & tment service & \\
\hline & Yes & 215 & 89.2 \\
\hline & No & 8 & 3.3 \\
\hline & Don’t know & 18 & 7.5 \\
\hline \multirow{2}{*}{$\begin{array}{l}\text { Facilities available- } \\
\text { inpatient/outpatient }\end{array}$} & Only outpatient facility & 231 & 95.9 \\
\hline & Both inpatient and outpatient facility & 10 & 4.1 \\
\hline \multirow{3}{*}{ Good infrastructure } & Available & 201 & 83.4 \\
\hline & Not available & 35 & 14.5 \\
\hline & Don't know & 05 & 2.1 \\
\hline \multirow{3}{*}{ Rehabilitation facility } & Available & 228 & 94.6 \\
\hline & Not available & 8 & 3.3 \\
\hline & Don't know & 05 & 2.1 \\
\hline \multirow{3}{*}{ Interventions preferred } & Only pharmacological & 05 & 2.1 \\
\hline & Only non-pharmacological & 05 & 2.1 \\
\hline & Pharmacological and non-pharmacological & 231 & 95.9 \\
\hline \multirow{2}{*}{ Adequate number of beds } & Yes & 166 & 68.9 \\
\hline & No & 75 & 31.1 \\
\hline \multirow{9}{*}{$\begin{array}{l}\text { Entertainment facility } \\
(n>241 \text { because of common } \\
\text { responses) }\end{array}$} & a) TV & 232 & 96.3 \\
\hline & b) CD/DVD player & 232 & 96.3 \\
\hline & c) Music system & 208 & 86.3 \\
\hline & d) Music instruments & 178 & 73.9 \\
\hline & e) Indoor games & 228 & 94.6 \\
\hline & f) Outdoor games & 169 & 70.1 \\
\hline & g) Gymnasium & & \\
\hline & i) Available & 135 & 56.0 \\
\hline & ii) Don't know & 07 & 2.9 \\
\hline \multirow{2}{*}{ Food served } & Only Vegetarian & 13 & 5.4 \\
\hline & Both & 228 & 94.6 \\
\hline
\end{tabular}


Table 2

\begin{tabular}{|c|c|c|c|}
\hline Variable & Category & Frequency & Percentage \\
\hline \multirow{2}{*}{ Nutritional supplement } & Fruits & 5 & 2.1 \\
\hline & None & 236 & 97.9 \\
\hline Proper cleanliness & Yes & 231 & 95.9 \\
\hline \multirow{2}{*}{$\begin{array}{l}\text { Adequate number of } \\
\text { toilet/bathroom available }\end{array}$} & Available & 175 & 72.6 \\
\hline & Not available & 66 & 27.4 \\
\hline \multirow{2}{*}{$\begin{array}{l}\text { Cleanliness of } \\
\text { toilet/bathroom }\end{array}$} & Yes & 225 & 93.4 \\
\hline & No & 16 & 6.6 \\
\hline \multirow{6}{*}{$\begin{array}{l}\text { Contact facility allowed } \\
(\mathrm{n}>241 \text { because of common } \\
\text { responses) }\end{array}$} & Incoming calls & 23 & 9.5 \\
\hline & Outgoing calls & 12 & 5.0 \\
\hline & Mobile & 05 & 2.1 \\
\hline & Parents' visit & 237 & 98.3 \\
\hline & Friends' & 110 & 45.6 \\
\hline & Relatives' visit & 122 & 50.6 \\
\hline \multirow{2}{*}{ Transport facility } & Yes & 236 & 97.9 \\
\hline & No & 5 & 2.1 \\
\hline \multirow{4}{*}{ Rules and regulations } & Very strict & 31 & 12.9 \\
\hline & Strict & 90 & 37.3 \\
\hline & Liberal & 24 & 10.0 \\
\hline & Moderate & 96 & 39.8 \\
\hline \multirow{5}{*}{ Education sessions } & Interesting and useful & 137 & 56.8 \\
\hline & Boring but useful & 39 & 16.2 \\
\hline & Interesting but useless & 20 & 8.3 \\
\hline & Boring and useless & 39 & 16.2 \\
\hline & Don’t know & 6 & 2.5 \\
\hline
\end{tabular}

Studies and government surveys have proved that the number of women and especially pregnant women addicts are less common and enter the treatment programme lesser than their counterparts. ${ }^{6}$ When compared with the study of Goel et al, the results of present study showed lower literacy (Amit Goel et al, 98\%), but had similarity in terms of the gender where most of the participants were males (Amit Goel et al, 2010-86\%), Hindu by religion (Priti A et al) and Nepali (Home department, government of Sikkim, 2008-69\%) by ethnicity. ${ }^{7-9}$ A high percentage of alcohol and/or other drug use among Nepalese population in this study can be explained by the fact that the predominant population in Sikkim is of Nepalese origin. ${ }^{7,9}$

Patient satisfaction with the treatment facilities measures the quality of services provided by the treatment centers. Satisfaction or perception feedback may help improvement of the quality services and may affect treatment outcome positively. ${ }^{10,11}$ The study also found that the respondents' perception was positive for the treatment centres in terms of availability of different treatment services, infrastructure, types of interventions, entertainment facilities, types of food served and cleanliness. However, more than $90 \%$ of participants wanted to have more contact facilities such as for keeping mobile phones or landline connection for getting the calls from home and friends. Also, a good percentage reported that they did not like the rules and regulations because of its strict nature, education and treatment session mainly because of their repetitive boring and non-useful nature. ${ }^{10}$ Healthy food and living habits may have positive treatment outcomes. Here, in this study no nutritional supplement was provided to the dependents which might be affecting the treatment outcome adversely. Because of scarcity of study on treatment satisfaction by the treatment seekers it was difficult to compare with other available results, but the result of present study focuses on some important issues. The dependents who come for the treatment have a number of emotional, social, financial problems and usually they present themselves with mental and physical illnesses. Therefore, they should be dealt with utmost care so that they feel the treatment center as their home. There is need of better communication, friendly but strict rules, interesting, useful education and treatment sessions.

\section{CONCLUSION}

This study was an endeavour to study the existing determinants of treatment of substance dependence in Sikkim, north east India with an emphasis on the availability of treatment facilities in the treatment centres, based on feedback from dependents who were undergoing treatment. To increase the acceptability (entry) of treatment by treatment seekers, there is a need of 
improving the quality of available treatment facilities at affordable level. This study will help in giving direction for future research in the state, by providing baseline information. Considering the scarce literature on this topic future research is needed especially in the area which studies whether the facilities of treatment centres affects treatment entry. Audit of acceptable and suitable treatment facilities, consumers' evaluation should be carried out on a regular basis at regional and national level.

Funding: No funding sources Conflict of interest: None declared

Ethical approval: The study was approved by the Institutional Ethics Committee and Institutional Research Protocol Evaluation Committee

\section{REFERENCES}

1. O'Brien CP. Drug addiction and drug abuse. In Brunton LL, Lazo JS, Parker KL editors. Goodman \& Gilman's The Pharmacological Basis of Therapeutics. $11^{\text {th }}$ Ed. New York: McGraw hill; 2006:607-609,662666.

2. Smyth BP, Barry J, Lane A, Cotter M, Maryo'neill, Quinn C, et al. In-patient treatment of opiate dependence: medium-term follow up outcomes. British journal of Psychiatry. 2005;187:360-5.

3. International Institute for Population Sciences and ORC Macro. National Family Health Survey (NFHS3). Sikkim; India: 2005-2006.

4. Nirash N. Grapling with drug addiction. The political and economic journal of Sikkim 2013 May;1(3):3841.

5. Grover S, Irpati AS, Saluja BS, Mattoo SK, Basu D. Substance-dependent women attending a de-addiction center in North India: Sociodemographic and clinical profile. Indian J Med Sci. 2005;59(7):283-91.

6. Jackson A, Shannon L. Barriers to receiving substance abuse treatment among rural pregnant women in Kentucky. Matern Child Health Journal. 2012;16(9):1762-70.

7. Goel A, Chakrabarti A. Prevalence and sociodemographic correlates of substance use in a rural community in Sikkim, North East India: Results from a pilot population survey. Journal of substance use. Jan 2010;15(1):13-23.

8. Priti A, Chavan BS, Kaur H. A Study of Reasons for not Seeking Treatment for Substance Abuse in Community. Indian Journal of Psychiatry. 2004;46(3):257.

9. Home Department, Government of Sikkim. 2008. Accessed on October 20, 2013. Available at: http://sikkim.nic.inhomedept/index2.htm.

10. Morrio ZS, Gannon M. Drug misuse treatment services in Scotland: predicting outcomes. International journal for quality in health care. 2008;20(4):271-6.

11. Braig S, Beutel M, Toepler E, Peter R. Client satisfaction with substance abuse treatment baseline results from the IQMS study conducted in seven counselling centres. Intl. J. Public Health. 2998;53(2):104-10.

Cite this article as: Pandey SK, Dass D. An assessment of available treatment facilities at different treatment centers of Sikkim: a cross sectional baseline study from dependents' perspective. Int J Basic Clin Pharmacol 2017;6:19215 . 